\title{
Antioxidant activities of solvent extracts from different Glehnia Radix parts and their inhibitory effect against nitric oxide production in Raw 264.7 cell
}

\author{
Yul-Ri Gu${ }^{1}$, Sun-Won Kim ${ }^{2}$, Yong-Won Son ${ }^{2}$, Joo-Heon Hong ${ }^{1 *}$ \\ ${ }^{1}$ Department of Food Science and Technology, Catholic University of Daegu, Gyeongsan 38430, Korea \\ ${ }^{2}$ Uljin Agricultural Technology Center, Uljin 36323, Korea
}

\section{해방풍 부위별 용매추출물의 항산화 활성 및 nitric oxide 생성 억제}

\author{
구율리 ${ }^{1} \cdot$ 김선원 $^{2} \cdot$ 손용원 ${ }^{2} \cdot$ 홍주헌 $^{1 *}$ \\ ${ }^{1}$ 대구가톨릭대학교 식품공학전공, ${ }^{2}$ 울진군 농업기술센터
}

\begin{abstract}
In this study, we compared the antioxidant and immuno-modulatory effects of water (HR, HL, HS), 70\% ethanol (ER, EL, ES), and 70\% methanol (MR, ML, MS) extracts of different parts (root, leaf, and seed) from Glehnia Radix. Yields were $17.40-30.17 \%$ for water extract, $11.47-28.67 \%$ for $70 \%$ ethanol extract, and $10.73-30.57 \%$ for 70\% methanol extract, respectively. The total polyphenol and flavonoid contents of EL were $10.79 \mathrm{~g} / 100 \mathrm{~g}$ and $2.01 \mathrm{~g} / 100 \mathrm{~g}$, respectively. The DPPH and ABTS radical scavenging activities of EL at 1,000 $\mu \mathrm{g} / \mathrm{mL}$ were $84.70 \%$ and 57.64\%, respectively. The superoxide radical scavenging and ferric-reducing antioxidant power of EL at 1,000 $\mu \mathrm{g} / \mathrm{mL}$ were $84.05 \%$ and $975.28 \mu \mathrm{M}$, respectively. Moreover, $70 \%$ ethanol and $70 \%$ methanol extracts of root from Glehnia Radix significantly inhibited production of NO in LPS-stimulated macrophage RAW 264.7 cells without cytotoxicity. These results suggest that $70 \%$ ethanol and $\mathbf{7 0} \%$ methanol extracts of Glehnia Radix leaf may be a useful functional food material in the food industry.
\end{abstract}

Key words : Glehnia Radix, solvent extract, antioxidant activity, nitric oxide production

\section{서 론}

최근 현대인들의 식습관이 변화하고, 삶의 질적 향상과 건강 기능성 식품과 의약품에 대한 인식변화에 따라 건강에 대한 관심이 높아지면서 노화억제, 성인병 예방 및 치료 등의 생리활성을 나타내는 약용식물에 대한 연구가 활발히 진행되고 있다(1). 이렇게 약용식물이 가지고 있는 다양한 기능성 성분의 개발과 그 효능에 대한 연구가 주목받기 시작하면서 우리가 예로부터 이용해 왔거나 혹은 그 이용가 능성을 아직 검증하지 못한 다양한 약용식물에 대한 관심도

*Corresponding author. E-mail : jhhong@cu.ac.kr Phone : 82-53-850-3218, Fax : 82-53-850-3218

Received 14 December 2016; Revised 28 December 2016; Accepted 28 December 2016.

Copyright (c) The Korean Society of Food Preservation. All rights reserved.
가 증가되고 있는 실정이다(2). 현재 천연 항산화제로 알려 져 있는 식물 소재의 주요 물질은 페놀 화합물로 밝혀져 있으며(3), 이러한 페놀 화합물은 인체 활성산소에 의한 산화적 손상을 방어한다고 보고되고 있다(4). 식품에 있어 서도 기능성을 지닌 제품에 대한 소비자들의 관심이 증가하 고 있는 관계로 이들 약용식물은 음료 및 가공식품의 주원 료 또는 부원료로 활용되며, 질병의 예방이나 치료, 건강 유지 등의 생체 기능 증강을 위한 소재로 다양하게 이용되 고 있다 $(5,6)$.

해방풍(Glehniae Radix cum Rhizoma)은 빈방풍 또는 해 사삼이라고도 하며, 해변가의 사구에서 자란다. 예로부터 한방에서 해방풍은 결핵성기침, 기관지염, 감기, 입이나 목 이 마르는 증세, 두통, 중풍, 신경통, 양음청열, 익위생진, 진통약, 피복양진, 발한, 경련, 간질 등에 효과가 있다고 나타나 있으며, 기관지염의 예방 및 폐결핵 우양과 관절염 치료에도 사용되고 있다(7). 해방풍에 관한 연구로는 해방 
풍 및 천남성 추출물이 CNS에 미치는 영향 및 항염증작용 (8), Glehnia littoralis의 수용성 추출물 및 유기용매를 이용 하여 추출한 추출물의 항산화 활성(9), Glehnia littoralis와 Saposhnikovia divaricata의 추출물이 LPS(lipopolysaccharide) 로 유발된 세포의 염증 억제작용(10) 등이 있으나, 해방풍 부위별 및 추출용매에 따른 항산화 활성 및 nitric oxide 생성 억제를 통한 항염증 효과 등 면역조절능에 대한 연구 는 미흡한 실정이다. 생물체는 대사과정 중 생화학 반응 및 외부 환경에 의해 인체에 유해한 활성산소종(reactive oxygen species)이 생성된다. 이는 산화적 스트레스로 작용 하여 체내의 DNA, 기질 및 효소 등을 파괴하여 세포조직의 심각한 손상을 야기하여 염증, 피부 노화 및 암 등 다양한 질환의 원인으로 알려져 있다 $(11,12)$. 활성산소의 과도한 생성과 이로 인한 nitric oxide의 축적은 인체의 면역조절 작용하는 대식세포의 지나친 활성을 유도하여 생체 내 필수 방어 작용인 염증의 과한 활성화를 일으켜 염증 관련 질환 을 유발한다(13). 이러한 관점에서 활성산소종을 제거하는 항산화 활성은 강조되고 있으며, 산화적 스트레스 및 염증 에 의한 질환을 예방 및 치료하기 위한 강력한 항산화 활성 및 항염 활성을 가지는 기능성 소재 개발을 위한 연구가 이루어지고 있다. 특히 안전하고 항산화 활성 및 항염 활성 이 뛰어난 각종 식물 등 천연자원에 대한 연구가 많은 관심 을 받고 있다(14).

따라서 본 연구에서는 해방풍 부위별 및 추출용매에 따 른 추출물의 항산화 활성과 RAW 264.7 대식세포주를 이용 하여 LPS 처리에 의해 증가한 nitric oxide의 생성억제능을 비교분석하여 항산화 활성 및 면역조절능을 가지는 해방풍 의 기능성소재 개발을 위한 기초자료로 이용하고자 실시하 였다.

\section{재료 및 방법}

\section{실험재료}

해방풍은 경상북도 울진군 농업기술센터로부터 제공받 았다. 해방풍의 뿌리, 잎 및 씨앗은 각각 $45^{\circ} \mathrm{C}$ 에서 24 시간 열풍 건조하였으며, 분쇄기(RT-04, Hanli Co., Sejong, Korea)로 분쇄하여 표준망체(60 mesh, Chung Gye Sang Cong Sa, Seoul, Korea)를 통과시킨 분말을 추출용 시료로 사용하였다.

\section{추출물의 제조}

추출물은 해방풍 부위별 분말 $30 \mathrm{~g}$ 에 고형분 대비 10 배의 증류수, $70 \%$ 에탄올 및 $70 \%$ 메탄올을 첨가하였다. 증류수 는 $100^{\circ} \mathrm{C}$ 에서 3 시간, $70 \%$ 에탄올 및 $70 \%$ 메탄올은 $80^{\circ} \mathrm{C}$ 에 서 3시간 동안 환류냉각추출기(CA-1112, Eyela Co., Tokyo, $\mathrm{Japan}$ )를 이용하여 추출하였고 각각의 추출물은 불순물을
제거하기 위하여 여과지(Whatman No. 2)를 이용하여 여과 하였다. 여과된 용액은 감압농축기(Model N-1N, Eyela Co., Tokyo, Japan)로 농축한 다음, 동결건조기(Free Zone 2.5, Labconco Co., Kansas, MO, USA)로 건조하여 $-70^{\circ} \mathrm{C}$ 이하의 암소에 보관하면서 분석용 시료로 사용하였다.

\section{추출수율}

해방풍 부위별 추출물의 수율은 동결건조(Free Zone 2.5 , Labconco Co.)한 다음 건물 중량을 구하였고 시료 조제에 사용한 원료 건물량에 대한 백분율로 나타내었다.

\section{총 폴리페놀 함량 및 총 플라보노이드 함량}

총 폴리페놀 함량은 Folin-Denis법(15)에 따라 시료 $1 \mathrm{~mL}$ 에 $1 \mathrm{~N}$ Folin Ciocalteu reagent $1 \mathrm{~mL}$ 를 첨가하고 충분히 혼합한 다음 $20 \% \mathrm{Na}_{2} \mathrm{CO}_{3} 1 \mathrm{~mL}$ 를 첨가하여 실온의 암소에 서 30 분간 반응시킨 후 분광광도계(Ultrospec 2100pro, Biochrom Ltd., Cambridge, UK)를 이용하여 $725 \mathrm{~nm}$ 에서 흡광도를 측정하였다. 총 폴리페놀 함량은 tannic acid (Sigma-Aldrich Co., St. Louis, MO, USA)를 사용하여 작성 한 표준곡선으로부터 계산하였다.

총 플라보노이드 함량은 Jia 등(16)의 방법을 응용하여 측정하였다. 시료 $1 \mathrm{~mL}$ 에 $5 \% \mathrm{NaNO}_{2} 150 \mu \mathrm{L}$ 를 혼합하여 실온에서 6분간 반응 시킨 후 $10 \% \mathrm{AlCl}_{3} 300 \mu \mathrm{L}$ 와 혼합하여 다시 실온에서 5 분간 반응 시킨 후 $1 \mathrm{~N} \mathrm{NaOH} 1 \mathrm{~mL}$ 와 혼합한 다음 분광광도계(Ultrospec 2100pro, Biochrom Ltd.) 를 이용하여 $510 \mathrm{~nm}$ 에서 흡광도를 측정하였다. 총 플라보 노이드함량은 rutin(Sigma-Aldrich Co.)을 사용하여 작성한 표준곡선으로부터 계산하였다.

\section{$\mathrm{DPPH}$ radical 소거활성 측정}

DPPH radical 소거활성은 1,1-diphenyl-2-pycrylhydrazyl $(\mathrm{DPPH})$ 의 환원력을 이용하여 측정하였다(17). 즉, DPPH reagent는 DPPH $12 \mathrm{mg}$ 을 absolute ethanol $100 \mathrm{~mL}$ 에 용해한 후 증류수 $100 \mathrm{~mL}$ 첨가하여 흡광도를 $517 \mathrm{~nm}$ 에서 약 1.6 으 로 조정하여 제조하였다. 시료 $0.5 \mathrm{~mL}$ 에 DPPH reagent 5 $\mathrm{mL}$ 를 혼합하여 실온에서 15 분간 반응시킨 후 분광광도계 (Ultrospec 2100pro, Biochrom Ltd.)로 흡광도를 측정하고 아래와 같이 계산하였다.

$$
\mathrm{DPPH} \text { radical 소거 활성(\%) }=1-\frac{\mathrm{S}}{\mathrm{C}} \times 100
$$

S : absorbance of sample at $517 \mathrm{~nm}$

C : absorbance of control at $517 \mathrm{~nm}$

\section{ABTS radical 소거활성 측정}

ABTS(2,2'-azino-bis(3-ethylbenzothiazoline-6-sulfonic 
acid)) radical 소거활성(18)은 $7.4 \mathrm{mM}$ ABTS(Sigma-Aldrich Co.)와 $2.45 \mathrm{mM}$ potassium persulfate를 최종 농도로 혼합하 여 실온인 암소에서 24시간 동안 방치하여 ABTS radical을 형성시킨 후 $732 \mathrm{~nm}$ 에서 흡광도 값이 $0.70 \pm 0.02$ 가 되게 phosphate buffer saline(PBS, pH 7.4)으로 희석하였다. 희석 된 용액 $180 \mu \mathrm{L}$ 에 시료 $20 \mu \mathrm{L}$ 를 혼합하여 정확히 1 분간 반응시킨 다음 분광광도계(Ultraspec 2100pro, Biochrom Ltd.)를 이용하여 $732 \mathrm{~nm}$ 에서 흡광도를 측정하였다. ABTS radical 소거활성은 추출물의 첨가 전과 후의 차이를 아래와 같이 백분율로 나타내었다.

ABTS radical 소거 활성 $(\%)=1-\frac{\mathrm{S}}{\mathrm{C}} \times 100$

S : absorbance of sample at $732 \mathrm{~nm}$

C : absorbance of control at $732 \mathrm{~nm}$

\section{Superoxide radical 소거활성 측정}

Superoxide radical 소거활성은 Nishikimi 등(19)의 방법에 따라 다음과 같이 측정하였다. 시료 $500 \mu \mathrm{L}$ 에 $0.1 \mathrm{M}$ Tris- $\mathrm{HCl}$ 완충용액(pH 8.5) $100 \mu \mathrm{L}, 100 \mu \mathrm{M}$ phenazine methosulfate(PMS, Sigma-Aldrich Co.) $200 \mu \mathrm{L}$ 를 혼합하여 반응 시킨 후 $500 \mu \mathrm{L}$ nitro blue tetrazolium(NBT, SigmaAldrich Co.) $200 \mu \mathrm{L}$ 및 $500 \mu \mathrm{M} \beta$-nicotinamide adenine dinucleotide(NADH, Sigma-Aldrich Co.) $400 \mu \mathrm{L}$ 를 첨가하여 실온에서 10 분간 반응시킨 다음 분광광도계(Ultraspec 2100pro, Biochrom Ltd.)를 이용하여 $560 \mathrm{~nm}$ 에서 흡광도를 측정하였다. Superoxide radical 소거활성은 추출물의 첨가 전과 후의 차이를 아래와 같이 백분율로 나타내었다.

Superoxide radical 소거 활성(\%) $=1-\frac{\mathrm{S}}{\mathrm{C}} \times 100$

S : absorbance of sample at $560 \mathrm{~nm}$

C : absorbance of control at $560 \mathrm{~nm}$

FRAP(ferric reducing antioxidant power) 측정

FRAP는 Benzie와 Strain의 방법(20)에 따라 다음과 같이 측정하였다. FRAP reagent는 $25 \mathrm{~mL}$ acetate buffer $(300 \mathrm{mM}$, $\mathrm{pH}$ 3.6)를 $37^{\circ} \mathrm{C}$ 에서 가온한 후, $40 \mathrm{mM} \mathrm{HCl}$ 에 용해한 10 $\mathrm{mM}$ 2,4,6-tris(2-pyridyl)-s-triazine(TPTZ, Sigma-Aldrich Co.) $2.5 \mathrm{~mL}$ 와 $20 \mathrm{mM}$ ferric chloride $\left(\mathrm{FeCl}_{3}\right) 2.5 \mathrm{~mL}$ 를 첨가하 여 제조하였다. 시료 $30 \mu \mathrm{L}$ 에 제조된 FRAP reagent 900 $\mu \mathrm{L}$ 와 증류수 $90 \mu \mathrm{L}$ 를 넣은 후 $37^{\circ} \mathrm{C}$ 에서 10 분간 반응시킨 후 분광광도계(Ultraspec 2100pro, Biochrom Ltd.)를 이용하 여 $510 \mathrm{~nm}$ 에서 흡광도를 측정하였다. $\mathrm{FRAP}$ 는 $\mathrm{FeSO}_{4}$. $7 \mathrm{H}_{2} \mathrm{O}$ (Sigma-Aldrich Co.)을 정량하여 작성한 표준곡선으 로부터 계산하였다.

\section{세포배양}

실험에 사용한 대식세포주인 RAW 264.7(KCTC No. 40071) 세포는 한국세포주은행(KTCC, Seoul, Korea)에서 분양받아 사용하였다. 세포배양은 DMEM 배지(Welgene, Daegu, Korea)를 이용하여 각각 $10 \%$ fetal bovine serum (Gibco BRL Co., Grand Island, NY, USA), 1\% penicillinstreptomycin(Gibco BRL Co.)을 첨가하여 배양하였다. 세포 는 모두 $37^{\circ} \mathrm{C}, 5 \% \mathrm{CO}_{2}$ incubactor(MCO-18 AIC, Sanyo Co., Osaka, Japan)에서 배양하였다.

\section{세포독성}

세포독성은 MTT assay로 측정하였으며, 배양된 세포주 를 $5 \times 10^{4}$ cell/well의 농도로 조정하여 96 well plate에 100 $\mu \mathrm{L}$ 씩 첨가하여 24 시간 배양하고 이후 새로운 배지에 시료 를 농도별로 처리한 다음 24 시간 동안 배양하였다. 배양 후 PBS 완충용액에 녹인 methyl thiazol-2-YL-2,5-diphenyl tetrazolium bromide $(5 \mathrm{mg} / \mathrm{mL}$, Sigma-Aldrich Co.) 용액을 각 well에 $10 \mu \mathrm{L}$ 씩 첨가하고 다시 4시간 동안 배양하여 MTT가 환원되도록 하였다. 이후 상등액을 완전히 제거하 고 dimethyl sulfoxide(DMSO, Jensei Chemical Co., Tokyo, Jpan) $100 \mu \mathrm{L}$ 를 각 well에 첨가하여 10 분간 반응시켜 formazan 결정을 완전히 용해한 다음 microplate reader (UVM-340, Asys Co., Biochrom, Cambridge, UK)를 이용하 여 $540 \mathrm{~nm}$ 에서 흡광도를 측정하였다.

\section{$\mathrm{NO}$ 생성량 측정}

RAW 264.7 세포를 $5 \times 10^{4}$ cell/well이 되도록 96well plate 에 각각 $100 \mu \mathrm{L}$ 씩 첨가하여 24시간 배양하고, 농도별 시료 및 lipopolysaccharide(LPS, $0.1 \mu \mathrm{g} / \mathrm{mL}$, Sigma-Aldrich Co.)를 처리하여 24시간 배양하였다. 배양이 완료된 후 상등액 50 $\mu \mathrm{L}$ 에 동량의 Griess 시약(Sigma-Aldrich Co.)을 혼합하여 10 분간 반응시킨 후 microplate reader(UVM-340, Asys Co.) 를 이용하여 $540 \mathrm{~nm}$ 에서 흡광도를 측정하였으며, NO 생성 량은 sodium nitrite(Sigma-Aldrich Co.)의 농도별 표준곡선 을 이용하여 계산하였다.

\section{통계처리}

모든 실험결과는 IBM SPSS Statistics(19.0, IBM Corp., Armonk, NY, USA)를 이용한 분산분석(ANOVA)을 실시하 였고 각 측정 평균값의 유의성 $(\mathrm{p}<0.05)$ 은 Duncan's multiple range test를 실시하여 검정하였다.

\section{결과 및 고찰}

\section{추출수율, 총 폴리페놀함량 및 총 플라보노이드함량}

해방풍 부위별 용매추출물의 추출수율, 총 폴리페놀 및 
총 플라보노이드 함량은 Table 1 과 같다. 추출용매에 따른 추출수율은 뿌리 및 씨앗 열수추출물이 다른 용매에 비해 높게 나타났으며, 부위별 추출수율은 뿌리의 경우 열수추 출물이, 잎은 $70 \%$ 메탄올 추출물에서 가장 높게 나타났다.

추출용매별 총 폴리페놀 함량은 $70 \%$ 에탄올 추출물에서 3.54-10.79 g/100 g으로 가장 높았으며, 70\% 메탄올 및 열수 추출물이 각각 $3.33-10.18 \mathrm{~g} / 100 \mathrm{~g}$ 및 $1.86-8.11 \mathrm{~g} / 100 \mathrm{~g}$ 으로 나타났다. 해방풍 부위별 총 폴리페놀 함량은 잎 추출물에 서 $10.79 \mathrm{~g} / 100 \mathrm{~g}$ 으로 나타났으며, 씨앗 및 뿌리 추출물이 각각 $9.30 \mathrm{~g} / 100 \mathrm{~g}$ 및 $3.54 \mathrm{~g} / 100 \mathrm{~g}$ 으로 나타나 뿌리부위의 폴리페놀 함량이 낮음을 확인하였다. 식물체에 함유되어 있는 페놀 화합물들은 다양한 항산화 활성 및 생리활성 기능을 가지고 있는데 이것은 분자 내 phenolic hydroxyl기 가 효소 단백질과 같은 거대 분자들과 결합하는 성격이 있어 이러한 생리활성 기능을 나타내는 주체로 인정되고 있다고 알려져 있다(21). 특히 항산화 활성과 관련하여 최근 생체 내에서의 산소 free radical 반응이 생체조직의 노화나 질병과 관련이 있어 페놀성 물질의 hydroxyl group은 유지 의 유리기 수용체로서 유지 산패의 초기 단계에 생성된 유리기들이 안정된 화합물을 형성하도록 하여 산화억제 작용을 한다. 즉 페놀 함량이 높게 나타남은 산화 억제 작용 이 높음을 의미한다(22). 추출용매에 따른 총 플라보노이드 함량은 $70 \%$ 에탄올 추출물에서 $0.79-2.01 \mathrm{~g} / 100 \mathrm{~g}$ 으로 가장 높게 나타났으며, $70 \%$ 메탄올 및 열수추출물이 각각 0.35-1.56 g/100 g 및 0.33-1.43 g/100 g으로 나타났다. 해방 풍 부위별 총 플라보노이드 함량은 잎 추출물에서 2.01 $\mathrm{g} / 100 \mathrm{~g}$ 으로 가장 높았고, 씨앗 및 뿌리 추출물이 각각 1.43

Table 1. Yield, total polyphenol, and total flavonoid contents of extracts from Glehniae Radix

\begin{tabular}{cccc}
\hline Sample $^{\mathrm{l})}$ & $\begin{array}{c}\text { Yield } \\
\text { (dry basis, \%) }\end{array}$ & $\begin{array}{c}\text { Total polyphenol } \\
(\text { TA, g/100 g) }\end{array}$ & $\begin{array}{c}\text { Total flavonoid } \\
\text { (Rutin, g/100) }\end{array}$ \\
\hline HR & $30.17 \pm 0.01^{\mathrm{ab} 2)}$ & $1.86 \pm 0.00^{\mathrm{i}}$ & $0.33 \pm 0.03^{\mathrm{h}}$ \\
HL & $28.33 \pm 0.15^{\mathrm{c}}$ & $5.52 \pm 0.05^{\mathrm{f}}$ & $1.12 \pm 0.01^{\mathrm{f}}$ \\
HS & $17.40 \pm 0.07^{\mathrm{f}}$ & $8.11 \pm 0.10^{\mathrm{e}}$ & $1.43 \pm 0.01^{\mathrm{c}}$ \\
\hline ER & $19.97 \pm 0.30^{\mathrm{e}}$ & $3.54 \pm 0.14^{\mathrm{g}}$ & $0.79 \pm 0.02^{\mathrm{g}}$ \\
EL & $28.67 \pm 0.04^{\mathrm{bc}}$ & $10.79 \pm 0.16^{\mathrm{a}}$ & $2.01 \pm 0.06^{\mathrm{a}}$ \\
ES & $11.47 \pm 0.11^{\mathrm{g}}$ & $9.30 \pm 0.11^{\mathrm{c}}$ & $1.36 \pm 0.05^{\mathrm{d}}$ \\
\hline MR & $23.20 \pm 0.20^{\mathrm{d}}$ & $3.33 \pm 0.13^{\mathrm{h}}$ & $0.35 \pm 0.00^{\mathrm{h}}$ \\
ML & $30.57 \pm 0.14^{\mathrm{a}}$ & $10.18 \pm 0.09^{\mathrm{b}}$ & $1.56 \pm 0.03^{\mathrm{b}}$ \\
MS & $10.73 \pm 0.19^{\mathrm{g}}$ & $8.88 \pm 0.08^{\mathrm{d}}$ & $1.21 \pm 0.01^{\mathrm{e}}$ \\
\hline
\end{tabular}

${ }^{1)} \mathrm{HR}$, hot-water extracts of root from Glehniae Radix, HL, hot-water extracts of leaf from Glehniae Radix, HS, hot-water extracts of seed from Glehniae Radix, ER, $70 \%$ ethanol extracts of root from Glehniae Radix, EL, 70\% ethanol extracts of leaf from Glehniae Radix, ES, $70 \%$ ethanol extracts of seed from Glehniae Radix MR, 70\% methanol extracts of root from Glehniae Radix, ML, 70\% methanol extracts of leaf from Glehniae Radix, MS, 70\% methanol extracts of seed from Glehniae Radix

${ }^{2)}$ Means \pm SD ( $n=3$ ) with different letters (a-i) above bars are significantly different by Duncan's multiple range test $(\mathrm{p}<0.05)$. $\mathrm{g} / 100 \mathrm{~g}$ 및 $0.79 \mathrm{~g} / 100 \mathrm{~g}$ 으로 나타나 총 폴리페놀 함량과 유사한 경향이었다. 추출용매의 경우 $70 \%$ 에탄올에서 총 폴리페놀 및 총 플라보노이드 함량이 가장 높게 나타났으 며, 해방풍 부위의 경우 잎 추출물이 가장 높음을 확인하였 다. 식물체에 함유되어 있는 폴리페놀은 만성질환에 강력 히 저항하는 기능성을 지닌 2차 대사산물이고 식물유래 식품에서 활성산소를 수용하는 역할을 하여 항산화 효과를 나타낸다고 보고하였으며(23), 폴리페놀과 플라보노이드 는 세포를 공격하는 유리라디칼(ROS, OH, NO)의 산화작용 을 억제 및 소거하는 기능기를 포함하고 있다(24). 또한 Wang 등(25)에 의하면 DPPH radical 소거능과 총 페놀 화합 물의 함량은 밀접한 상관관계가 있음이 보고된 바 있다. 이에 근거하여 총 폴리페놀 및 총 플라보노이드 함량이 높게 나타난 $70 \%$ 에탄올 잎 추출물이 항산화 활성이 우수 할 것으로 사료되었다.

\section{DPPH radical 및 ABTS radical 소거활성}

해방풍 부위별 용매추출물의 DPPH radical 및 ABTS radical 소거활성은 Fig. 1 및 2와 같다. DPPH radical 소거활 성은 모든 시료에서 농도 의존적으로 증가하였으며, 추출 용매의 경우 $70 \%$ 에탄올 및 $70 \%$ 메탄올 추출물에서 각각 4.09-84.70\% 및 4.31-83.26\%로 열수추출물에 비해 높은 항 산화 활성을 나타내었다. 해방풍 부위별 DPPH radical 소거 활성은 잎 추출물에서 $84.70 \%$ 로 가장 높았고, 씨앗 및 뿌리 추출물에서 $75.56 \%$ 및 $25.05 \%$ 으로 나타나 뿌리 추출물이 가장 낮았다. ABTS radical 소거활성은 모든 시료에서 농도 의존적으로 활성이 증가하였으며, $70 \%$ 에탄올 및 $70 \%$ 메 탄올 추출물에서 각각 9.58-57.64\% 및 9.49-52.31\%로 높은 활성을 나타내었다. 해방풍 부위별 용매추출물의 경우, $\mathrm{DPPH}$ radical 소거활성과 같이 잎 추출물에서 $57.64 \%$ 로 가장 높은 활성을 나타내었으며, 씨앗 및 뿌리 추출물에서 각각 $34.64 \%$ 및 $16.06 \%$ 으로 나타났다. Kwon 등(26)의 연구 결과에서 산겨릅나무의 DPPH radical 소거활성이 에탄올 추출물, 열수 추출물 및 수용액 분획물이 각각 $85.30 \%$, $77.70 \%$ 및 $79.80 \%$ 로 에탄올 추출물에서 높게 나타났다고 보고하여 본 연구와 유사한 경향이었다. 또한 총 폴리페놀 및 총 플라보노이드 함량이 높게 나타난 잎 $70 \%$ 에탄올 추출물이 DPPH 및 ABTS radical 소거활성에서도 높은 활 성을 나타내어 총 폴리페놀 함량이 증가하면 항산화 활성도 증가한다는 Seo 등(27)과 Lee 등(28)의 보고와 유사하였다.

\section{Superoxide radical 소거활성 및 FRAP 활성}

해방풍 부위별 용매추출물의 superoxide radical 소거활성 및 FRAP 활성은 Fig. 3 및 4와 같다. Superoxide radical 소거활성은 $70 \%$ 에탄올 및 $70 \%$ 메탄올 추출물에서 각각 3.26-84.05\% 및 2.06-72.38\%로 높은 항산화 활성을 나타내 었다. 해방풍 부위별 superoxide radical 소거활성은 잎 추출 
(A)

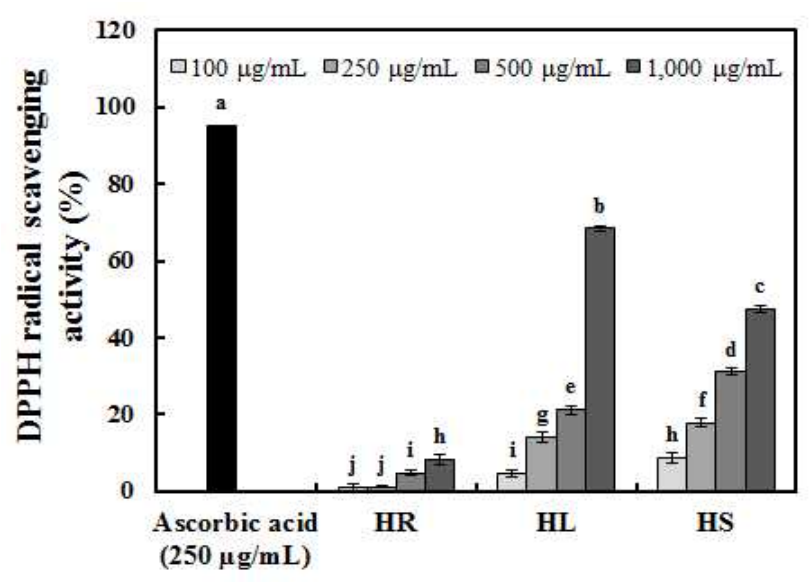

(B)

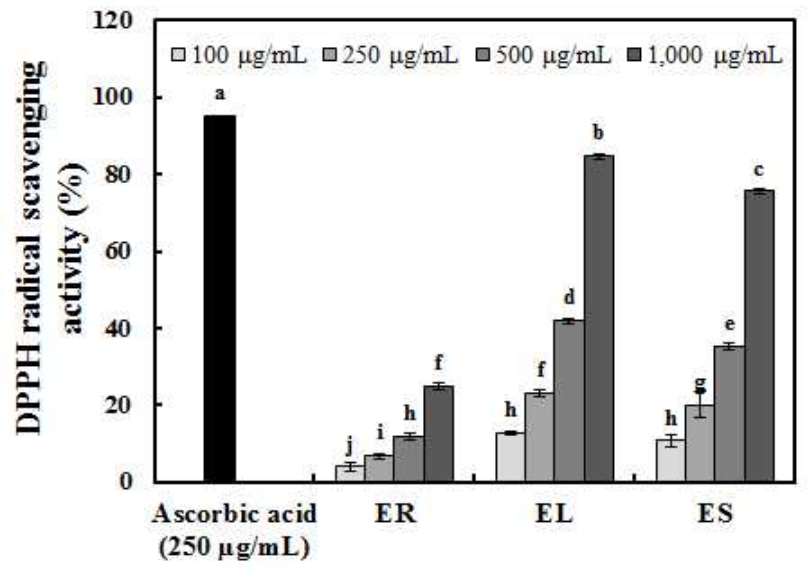

(C)

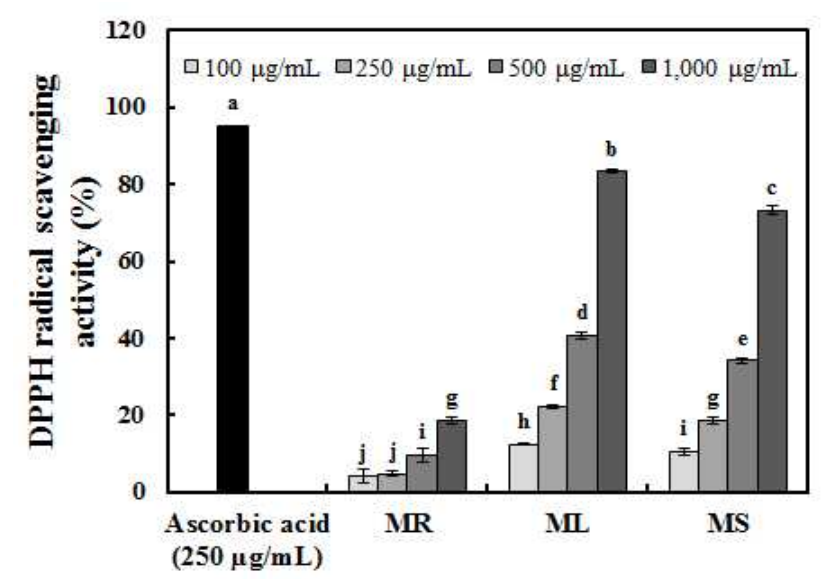

Fig. 1. DPPH radical scavenging activity of extracts from Glehniae Radix.

(A) HR, hot-water extracts of root from Glehniae Radix, HL, hot-water extracts of leaf from Glehniae Radix, HS, hot-water extracts of seed from Glehniae Radix (B) ER, 70\% ethanol extracts of root from Glehniae Radix. EL, 70\% ethanol extracts of leaf from Glehniae Radix. (C) ES, 70\% ethanol extracts of seed from Glehniae Radix, MR, 70\% methanol extracts of root from Glehniae Radix, ML, 70\% methanol extracts of leaf from Glehniae Radix. MS, 70\% methanol extracts of seed from Glehniae Radix Means \pm SD ( $(n=3)$ with different letters $(a-j)$ above bars are significantly different by Duncan's multiple range test $(\mathrm{p}<0.05)$.
(A)

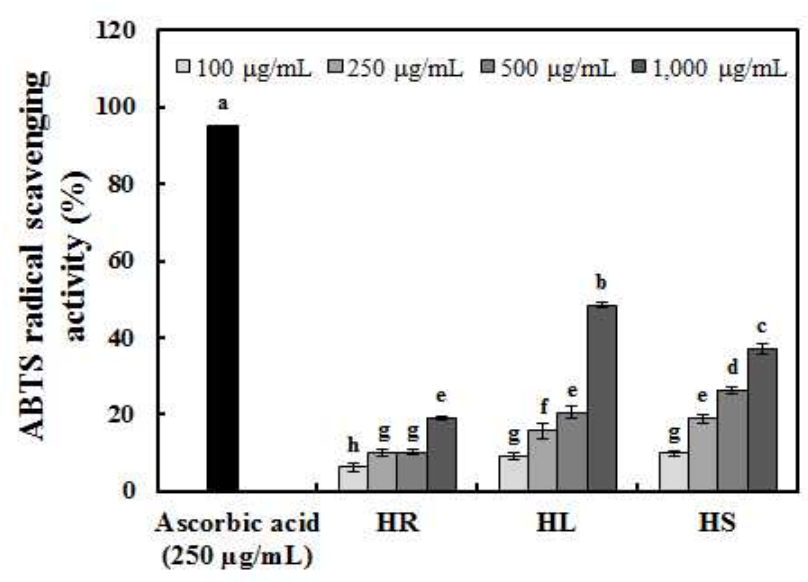

(B)

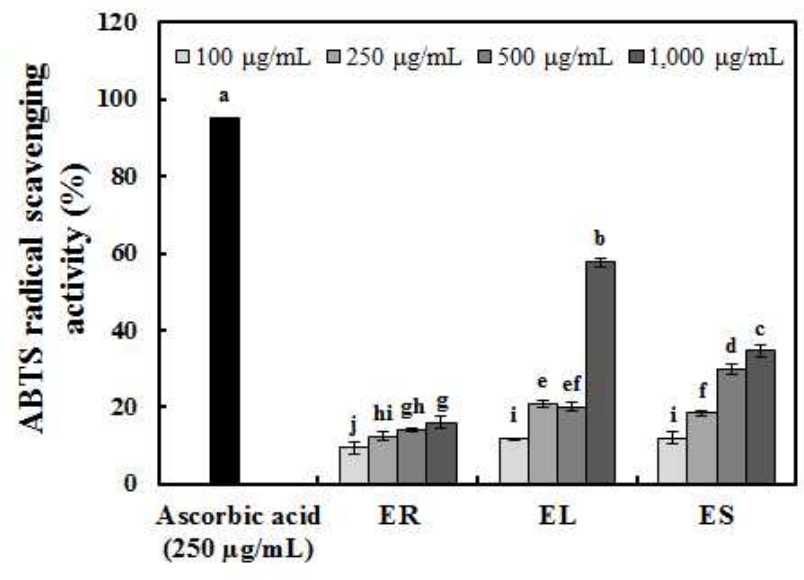

(C)

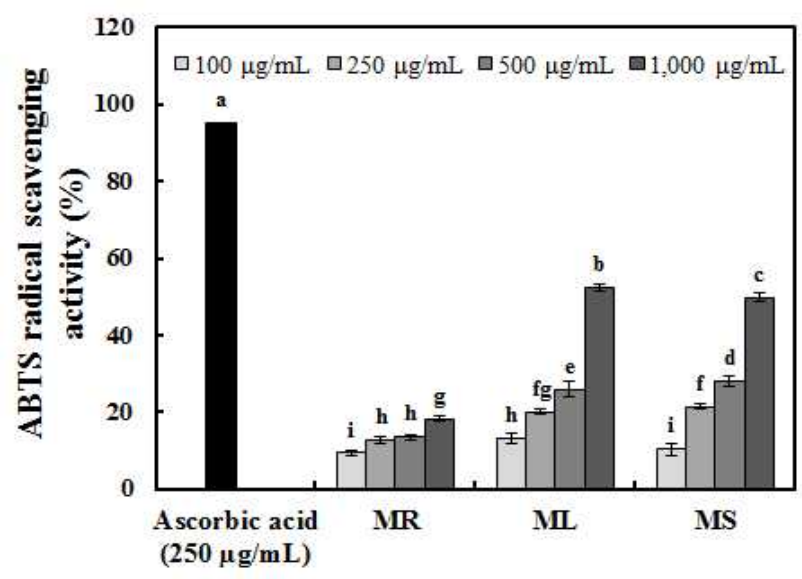

Fig. 2. ABTS radical scavenging activity of extracts from Glehniae Radix.

(A) HR, hot-water extracts of root from Glehniae Radix, HL, hot-water extracts of leaf from Glehniae Radix, HS, hot-water extracts of seed from Glehniae Radix (B) ER, 70\% ethanol extracts of root from Glehniae Radix, EL, 70\% ethanol extracts of leaf from Glehniae Radix. (C) ES, 70\% ethanol extracts of seed from Glehniae Radix MR, $70 \%$ methanol extracts of root from Glehniae Radix, ML, 70\% methanol extracts of leaf from Glehniae Radix MS, 70\% methanol extracts of seed from Glehniae Radix Means $\pm \mathrm{SD}(\mathrm{n}=3)$ with different letters $(\mathrm{a}-\mathrm{j})$ above bars are significantly different by Duncan's multiple range test $(\mathrm{p}<0.05)$. 
(A)

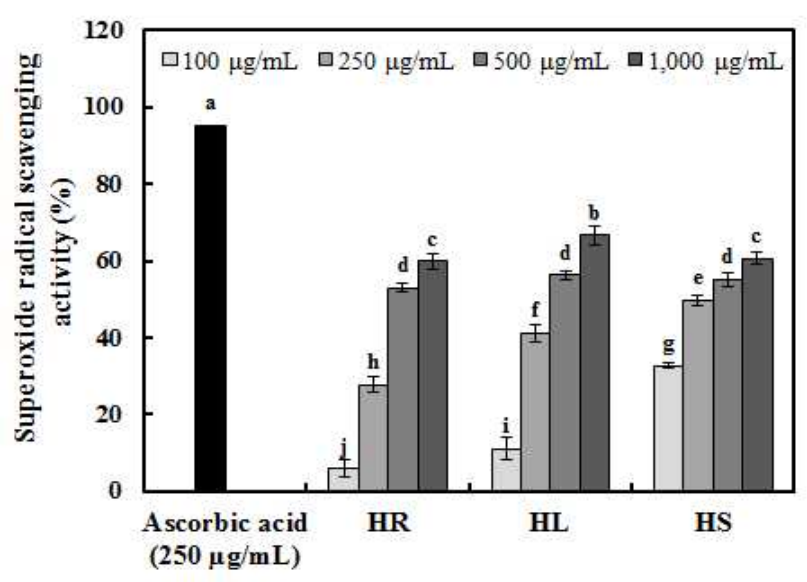

(B)

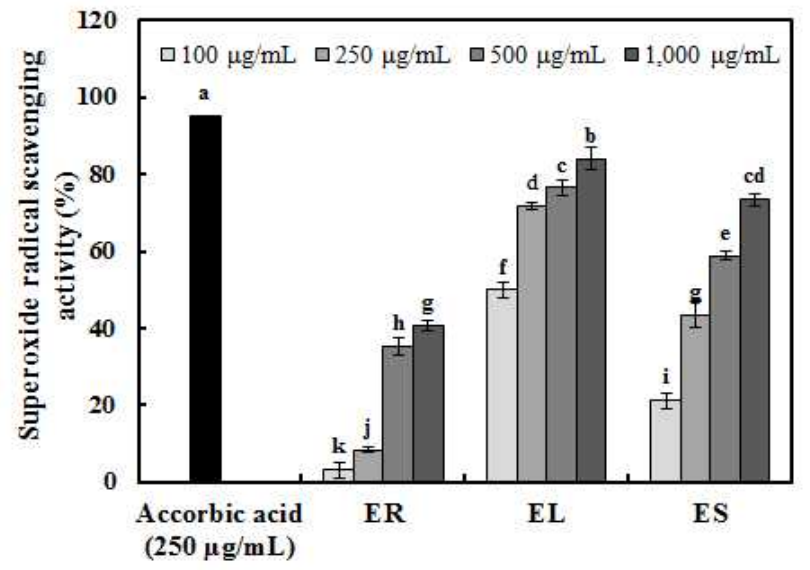

(C)

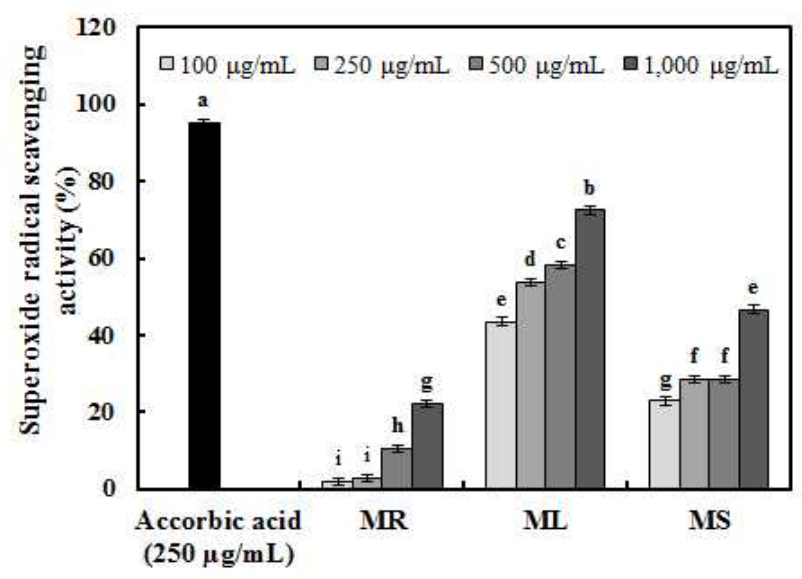

Fig. 3. Superoxide radical scavenging activity of extracts from Glehniae Radix.

(A) HR, hot-water extracts of root from Glehniae Radix, HL, hot-water extracts of leaf from Glehniae Radix, HS, hot-water extracts of seed from Glehniae Radix (B) ER, 70\% ethanol extracts of root from Glehniae Radix. EL, 70\% ethanol extracts of leaf from Glehniae Radix. (C) ES, 70\% ethanol extracts of seed from Glehniae Radix, MR, 70\% methanol extracts of root from Glehniae Radix, ML, 70\% methanol extracts of leaf from Glehniae Radix. MS, 70\% methanol extracts of seed from Glehniae Radix Means \pm SD $(n=3)$ with different letters $(a-k)$ above bars are significantly different by Duncan's multiple range test $(\mathrm{p}<0.05)$.

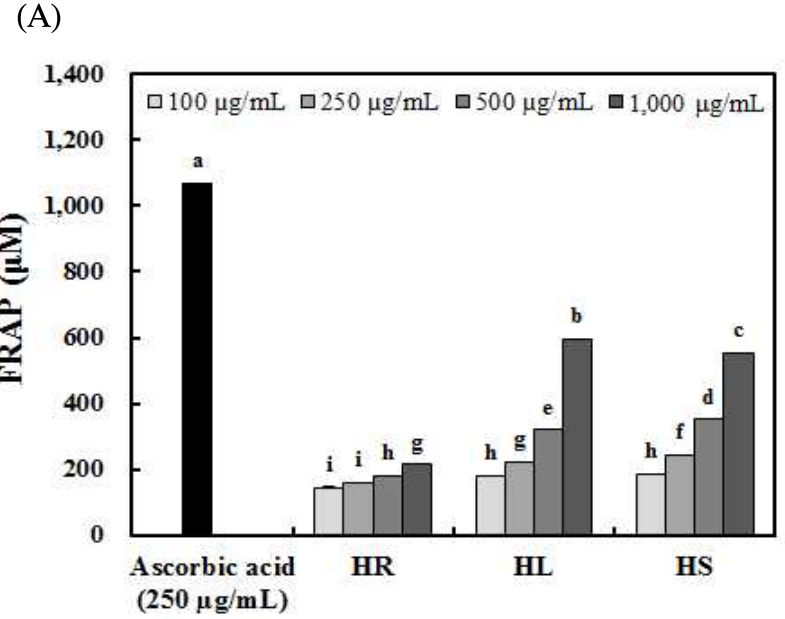

(B)

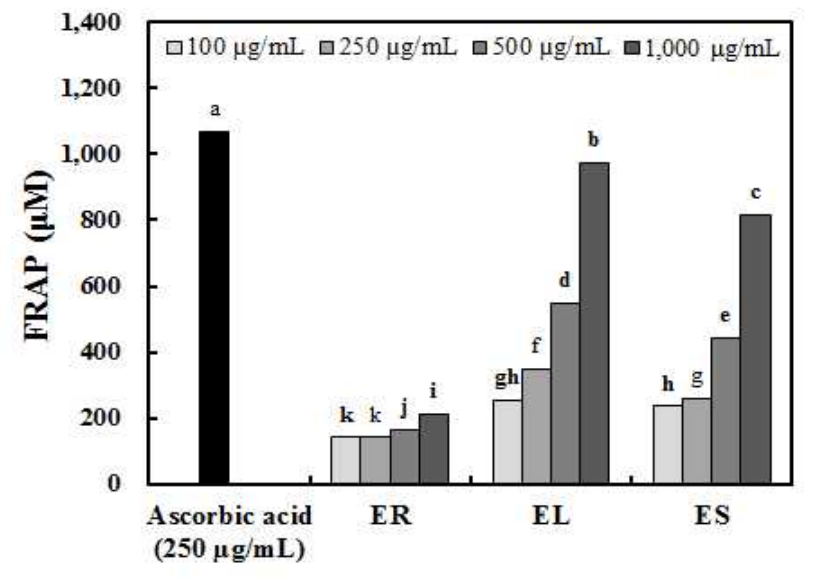

(C)

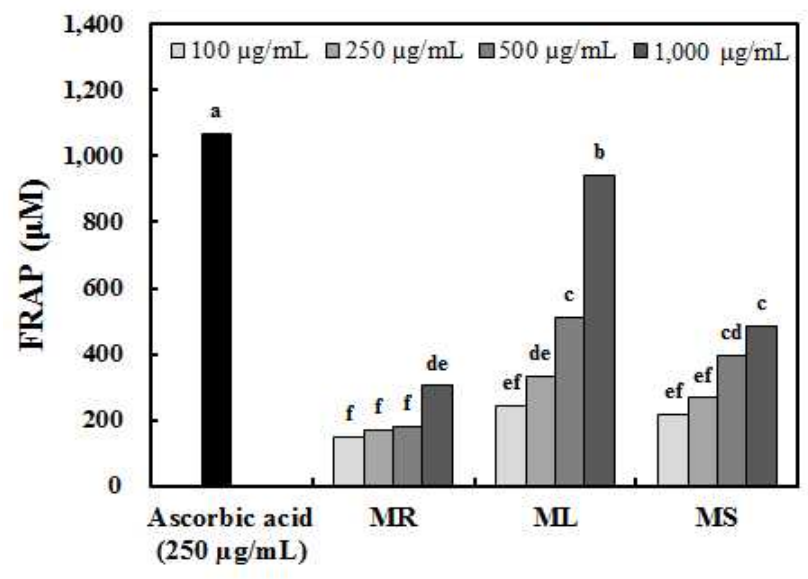

Fig. 4. FRAP(ferric reducing antioxidant power) activity of extracts from Glehniae Radix.

(A) HR, hot-water extracts of root from Glehniae Radix, HL, hot-water extracts of leaf from Glehniae Radix, HS, hot-water extracts of seed from Glehniae Radix (B) ER, 70\% ethanol extracts of root from Glehniae Radix, EL, 70\% ethanol extracts of leaf from Glehniae Radix (C) ES, 70\% ethanol extracts of seed from Glehniae Radix MR, $70 \%$ methanol extracts of root from Glehniae Radix, ML, 70\% methanol extracts of leaf from Glehniae Radix MS, 70\% methanol extracts of seed from Glehniae Radix Means $\pm \mathrm{SD}(\mathrm{n}=3)$ with different letters $(\mathrm{a}-\mathrm{k})$ above bars are significantly different by Duncan's multiple range test $(\mathrm{p}<0.05)$. 
물에서 11.15-84.05\%로 가장 높은 활성을 나타내었으며, 씨앗 및 뿌리 추출물에서 각각 $32.76-73.41 \%$ 및 5.83$40.82 \%$ 으로 나타나 $1,000 \mathrm{\mu g} / \mathrm{mL}$ 농도에서 잎 추출물은 뿌 리 추출물에 비해 대략 2 배 높은 항산화 활성을 나타내었다.

FRAP 활성은 모든 시료에서 농도 의존적으로 활성이 증가하였으며. 추출용매별 FRAP 활성은 $70 \%$ 에탄올 및 $70 \%$ 메탄올 추출물에서 각각 $142.38-975.25 \mu \mathrm{M}$ 및 148.20-942.47 $\mu \mathrm{M}$ 로 높은 활성을 나타내었다. 해방풍 부위 별 용매추출물의 FRAP 활성은 잎 추출물에서 $975.25 \mu \mathrm{M}$ 로 가장 높은 활성을 나타내었으며, 씨앗 및 뿌리 추출물에서 각각 $815.72 \mu \mathrm{M}$ 및 $212.51 \mu \mathrm{M}$ 으로 나타나 $1,000 \mu \mathrm{g} / \mathrm{mL}$ 농도에서 잎 추출물은 뿌리 추출물에 비해 약 4 배 높은 항산화 활성을 나타내었다. 이는 superoxide radical 소거활 성과 유사한 경향을 나타내었으며, Kim 등(29)의 연구에서 어성초 열수 추출물의 경우 $375.9 \mu \mathrm{M}$ Trolox/g extract, $70 \%$ 에탄올 추출물의 경우 $860.5 \mu \mathrm{M}$ Trolox/g extract로 나타나 $70 \%$ 에탄올 추출물이 열수 추출물에 비해 2.29배 유의적으 로 효과가 있다고 보고하여 본 연구와 유사하였다. 식물에 포함되어 있는 다양한 페놀산 및 플라보노이드는 산화·환 원에 영향을 미친다고 보고하였으며(30), 본 연구를 통해 국내 자생 해방풍 부위별 추출물이 철 이온 환원력에 탁월 한 효과가 있음을 증명하였으며 해방풍 잎 추출물은 다양한 라디칼에 대한 소거활성이 다른 부위에 비해 우수하여 생체 내 산화적 스트레스에 대한 항산화 물질로써 활용 가능함을 확인하였다.

\section{Nitric oxide 생성 억제}

해방풍 부위별 열수추출물(10-1,000 $\mathrm{\mu g} / \mathrm{mL})$ 과 해방풍 부 위별 $70 \%$ 에탄올 및 $70 \%$ 메탄올 추출물 $(1-50 \mu \mathrm{g} / \mathrm{mL})$ 을 처리하였을 때 모든 시료에서 $95 \%$ 이상 세포 생존율이 나타나 세포독성이 없음을 확인하여 nitric oxide 생성 억제 세포실험의 농도로 설정하였다.

대식세포에서 염증 매개인자인 nitric oxide(NO)는 박테 리아를 죽이거나 종양을 제거시키는 중요한 역할을 하지 만, 병리적인 원인에 의한 과도한 $\mathrm{NO}$ 의 형성은 산화적 스트 레스로 작용하여 세포 손상을 일으키고, 염증 및 암을 유발 한다(31-34). 이러한 산화적 스트레스를 제거하기 위해 항 산화 및 항염 효과가 증요하다. 따라서, 추출용매에 따른 해방풍 부위별의 항염 활성을 확인하기 위해 lipopolysaccharide (LPS, $0.1 \mu \mathrm{g} / \mathrm{mL}$ )로 자극을 유도한 Raw 264.7 세포를 이용 하여 NO의 생성에 미치는 영향을 분석하였다(Fig. 5). 모든 시료에서 농도 의존적으로 LPS에 유도되어 생성된 NO량 이 감소하는 것을 확인하였다. 추출용매에 따른 $\mathrm{NO}$ 량은 $50 \mu \mathrm{g} / \mathrm{mL}$ 농도에서 $70 \%$ 에탄올 및 $70 \%$ 메탄올 추출물이 각각 $5.25 \mu \mathrm{M}$ 및 $5.93 \mu \mathrm{M}$ 로 가장 낮은 nitric oxide 생성량을 보였으며, 해방풍 부위별에 따른 nitric oxide 생성량은 50 $\mu \mathrm{g} / \mathrm{mL}$ 에서 뿌리 및 잎 추출물이 각각 $5.25 \mu \mathrm{M}$ 및 $9.80 \mu \mathrm{M}$ 로
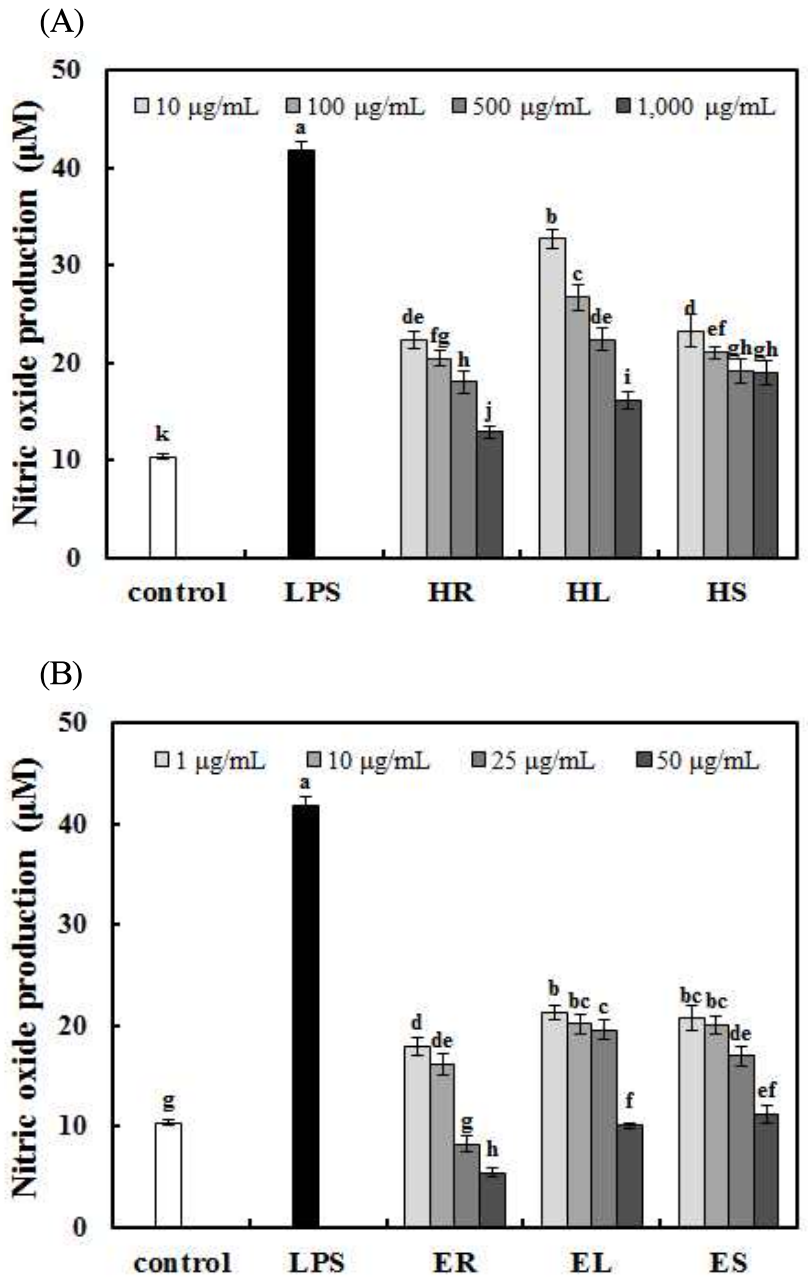

(C)

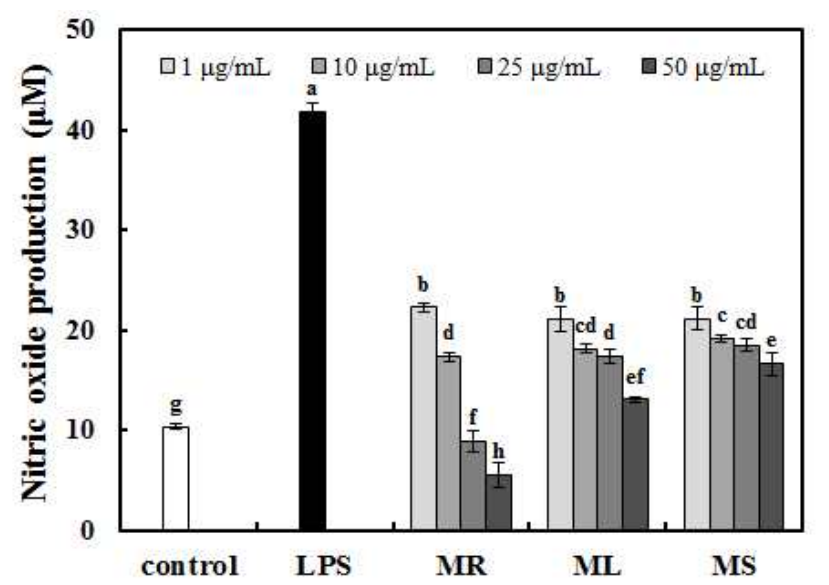

Fig. 5. Effect of polysaccharide extracts from Glehniae Radix on the nitric oxide production by Raw 264.7 cell.

(A) HR, hot-water extracts of root from Glehniae Radix, HL, hot-water extracts of leaf from Glehniae Radix, HS, hot-water extracts of seed from Glehniae Radix (B) ER, 70\% ethanol extracts of root from Glehniae Radix, EL, 70\% ethanol extracts of leaf from Glehniae Radix (C) ES, 70\% ethanol extracts of seed from Glehniae Radix, MR, $70 \%$ methanol extracts of root from Glehniae Radix, ML, 70\% methanol extracts of leaf from Glehniae Radix MS, 70\% methanol extracts of seed from Glehniae Radix Means $\pm \mathrm{SD}(\mathrm{n}=3)$ with different letters $(\mathrm{a}-\mathrm{k})$ above bars are significantly different by Duncan's multiple range test $(\mathrm{p}<0.05)$. 
가장 낮은 nitric oxide 생성량을 나타내었다. 앞서 실험한 항산화 활성과 비교하였을 때, 추출용매에 따른 활성은 $70 \%$ 에탄올 및 $70 \%$ 메탄올 추출물에서 우수한 항산화 활성 과 낮은 nitric oxide 생성량을 나태었으며, 해방풍 부위별에 따른 활성은 항산화 활성에서는 잎, 씨앗 및 뿌리 순으로 우수한 활성이 나타났으나, nitric oxide 생성량은 뿌리, 잎 및 씨앗 순으로 낮은 nitric oxide 생성량을 나타내었다. $\operatorname{Kim}(35)$ 의 연구에서 LPS로 RAW 264.7 세포를 자극시킨 후 방풍정제물이 10 여 가지의 inflammatory mediator의 억 제를 통해 염증반응을 제어한다고 보고하여 본 연구와 유사 한 경향을 나타내었으며, 이에 따라 해방풍은 염증반응을 일으키는 NO 생성을 억제하는 것을 확인하였다.

\section{요 약}

해방풍이 가지는 건강 기능성 소재로서의 가치를 확인하 고자, 해방풍 부위별 용매추출물의 항산화 활성 및 면역조 절 효과를 조사하였다. 해방풍 부위별 용매추출물의 추출 수율은 10.73-30.57이며, 총 폴리페놀 및 총 플라보노이드 함량은 해방풍 잎 $70 \%$ 에탄올 추출물(EL)에서 각각 10.79 $\mathrm{g} / 100 \mathrm{~g}$ 및 $2.01 \mathrm{~g} / 100 \mathrm{~g}$ 으로 가장 높은 값을 나타내었다. DPPH radical 및 ABTS radical 소거활성은 해방풍 잎 $70 \%$ 에탄올 추출물(EL)이 $100-1,000 \mathrm{\mu g} / \mathrm{mL}$ 농도에서 $12.90-$ $84.70 \%$ 및 11.78-57.64\%로 가장 우수한 radical 소거활성을 나타내었으며, superoxide radical 소거활성 및 FRAP 활성은 해방풍 잎 $70 \%$ 에탄올 추출물(EL)이 $100-1,000 \mu \mathrm{g} / \mathrm{mL}$ 농도 에서 각각 49.91-84.05\% 및 255.38-975.28 $\mathrm{lM}$ 로 가장 우수 한 활성을 나타내었다. 대식세포주인 RAW 264.7 세포에 해방풍 부위별 용매추출물을 처리하였을 때 nitric oxide 생성 억제능을 확인하기 위해 분석한 결과, 추출용매에 따 른 nitric oxide 생성량은 $70 \%$ 에탄올 및 $70 \%$ 메탄올 추출물 에서 가장 낮은 생성량을 보였으며, 해방풍 부위별에 따른 nitric oxide 생성량은 뿌리, 잎 및 씨앗 순으로 낮았다. 그 중에서 해방풍 뿌리 $70 \%$ 에탄올 추출물(ER)에서 가장 낮은 nitric oxide 생성량을 보여 우수한 nitric oxide 억제 효과를 확인하였으며, 이를 이용하여 기능성 소재, 미용식품 및 화장품 제조용 원료 등 다양하게 활용 가능할 것으로 사료 된다.

\section{References}

1. Kim SY, Ryu KS, Lee WC, Ku HO, Lee HS, Lee KR (1999) Hypoglycemic effect of mulberry leaves with anaerobic treatment in alloxan-induced diabetic mice. Kor J Pharmacogn, 30, 123-129
2. Cho IS, Han YH, Lee GY, Park KY (2007) Search for medicinal plants on improvable effect of intestinal microflora. Korean J Medicinal Crop Sci, 15, 26-29

3. Ju JC, Shin JH, Lee SJ, Cho HS, Sung NJ (2006) Antioxidative activity of hot water extracts from medicinal plants. J Korean Soc Food Sci Nutr, 35, 7-14

4. Kang KJ, Chung MS (1995) A survey on housewives, consumption pattern and nutrition knowledge about vegetables. Korean J Dietary Culture, 10, 377-390

5. Ham SS, Lee SY, Oh DH, Kim SH, Hong JK (1997) Development of beverages drinks using mountain edible herbs. J Korean Soc Food Sci Nutr, 26, 92-97

6. Yu AR, Park HY, Choi IW, Park YK, Hong HD, Choi HD (2012) Immune enhancing effect of medicinal herb extracts on a RAW 264.7 macrophage cell line. J Korean Soc Food Sci Nutr, 41, 1521-1527

7. Kim JH (2008) Active compounds from Glehniae Radix cum Rhizoma. MS Thesis, Chung-ang University, Korea, p 80

8. Cho SI, Lee EB, Cho TS (1985) Pharmacological studies on Glehniae Radix and Arisaematis Rhizoma. Kor J Pharmacogn, 16, 50-51

9. Ng TB, Liu F, Wang HX (2004) The antioxidant effects of aqueous and organic extracts of Panax quinquefolium, Panax notoginseng, Codonopsis pilosula, Pseudostellaria heterophylla and Glehnia littoralis. J Ethnopharmacol, 93, 285-288

10. Kim DM (2006) Comparative study of anti-inflammatory effects on roots of Glehnia littoralis and Saposhnikovia divaricata. MS Thesis, Kyunghee University, Korea, $\mathrm{p}$ 34

11. Chawla A, Nguyen KD, Goh YPS (2011) Macrophagemediated inflammation in metabolic disease. Nat Rev Immunol, 11, 738-749

12. Cencioni C, Spallotta F, Martelli F, Valente S, Mai A, Zeiher AM, Gaetano C (2013) Oxidative stress and epigenetic regulation in ageing and age-related diseases. Int Mol Sci, 14, 17643-17663

13. Sivaranjani N, Rao SV, Rajeev G (2013) Role of reactive oxygen species and antioxidants in atopic dermatitis. J Clin Diagn Res, 7, 2683-2685

14. Im DY, Lee KI (2013) Antioxidant activity and tyrosinase inhibition effect of ethanol extract and its fractions from the branch of Rhododendron schlippenbachii. Korean J Medicinal Crop Sci, 21, 439-443

15. Singleton VL, Rossi JA (1965) Colorimetry of total phenolics with phosphomolybdic-phosphotungstic acid 
reagents. AM J Enol Vitic, 16, 144-158

16. Jia Z, Tang M, Wu J (1999) The determination of flavonoid contents in mulberry and their scavenging effects on superoxide radicals. Food Chem, 64, 555-559

17. Blois MS (1958) Antioxidant determinations by the use of a stable free radical. Nature, 181, 1199-1200

18. Re R, Pellegrini N, Proteggente A, Pannala A, Yang M, Rice-Evans C (1999) Antioxidant activity applying an improved ABTS radical cation decolorization assay. Free Radic Biol Med, 26, 1231-1237

19. Benzie IFF, Strain JJ (1996) The ferric reducing ability of plasma (FRAP) as a measure of "antioxidant power" the FRAP assay. Anal Biochem, 239, 70-76

20. Oyaizu M (1986) Studies on products of browning reaction antioxidative activities of products of browning reaction prepared from glucosamine. Jpn J Nutr Diet, 44, 307-315

21. Choi SY, Cho HS, Sung NJ (2006) The antioxidative and nitrite scavenging ability of solvent extracts from wild grape (Vitis Coignetiea) skin. J Korean Soc Food Sci Nutr, 35, 961-966

22. Lee SO, Lee HJ, Yu MH, Im HG, Lee IS (2005) Total polyphenol contents and antioxidant activities of methanol extracts from vegetables produced in Ullung island. Korean J Food Sci Technol, 37, 233-240

23. Singleton VL, Orthofer R, Lamuela-Raventos RM (1999) Analysis of total phenols and other oxidation substrates and antioxidants by means of Folin-Ciocalteau reagent. Method Enzymol, 299, 152-177

24. Qi Y, Zhao X, Lim YI, Park KY (2013) Antioxidant and anticancer effects of edible and medicinal mushrooms. J Korean Soc Food Sci Nutr, 42, 655-662

25. Wang SY, Chang HN, Lin KT, Lo CP, Yang NS, Shyur LF (2003) Antioxidant properties and phytochemical characteristics of extracts from Lactuca indica. J Agric Food Chem, 51, 1506-1512

26. Kwon HN, Park JR, Jeon JR (2008) Antioxidative and hepato protective effects of Acer tegmentosum M. extracts. J Korean Soc Food Sci Nutr, 37, 1389-1394
27. Seo YH, Kim IJ, Yie AS, Min HK (1999) Electron donationg ability and contents of phenolic compounds, tocopherols and carotenoids in waxy corn (Zea mays L.). Korean J Food Sci Technol, 31, 581-585

28. Kim HK, Kwon YJ, Kim KH, Jeong YH (2000) Changes of total polyphenol content and electron donating ability of Aster glehni extracts with different microwave-assisted extraction conditions. Korean J Food Sci Technol, 32, $1022-1028$

29. Kim HS, Kim MJ, Cheong C, Kang SA (2013) Antioxidant properties in water and $70 \%$ ethanol extracts of Houttuynia Cordata Thunb. Journal of Korea Academia-Industrual cooperation Society, 14, 5091-5096

30. Rice-Evans CA, Miller NJ, Paganga G (1996) Structure antioxidant activity relationships of flavonoids and phenolic acid. Free Radic Biol Med, 20, 933-956

31. Stuehr DJ, Cho HJ, Kwon NS, Weise MF, Nathan CF (1991) Purification and characterization of the cytokine-induced macrophage nitric oxide synthase: an FAD-and FMN-containing flavoprotein. Proc Natl Acad Sci USA, 88, 7773-7777

32. McCartney-Francis N, Allen JB, Mizel DE, Albina JE, Xie QW, Nathan CF, Wahl SM (1993) Supperession of arthritis by an inhibitor of nitric oxide synthase. J Exp Med, 178, 749-754

33. Weisz A, Cicatiello L, Esumi H (1996) Regulation of the mouse inducible-type nitric oxide synthase gene promoter by interferon-gamma, bacterial lipopolysaccharide and NG-monomethyl-L-arginine. Biochem J, 316, 209-215

34. Omata N, Tsukahara H, Ito S, Ohshima Y, Yasutomi M, Yamada A, Jiang M, Hiraoka M, Nambu M, Deguchi Y, Mayumi M (2001) Increased oxidative stress in childhood atopic dermatitis. Life Sci, 69, 223-228

35. Kim JN (2015) Effects of Sec-O-glucosylhamaudol, a compound from Peucedanum japonicum Thunb extract on the LPS-Stimulated RAW 264.7 cell lines. MS Thesis, Chosun University, Korea, p 19 